EMPOWER: Jurnal Pengembangan Masyarakat Islam

Vol. 5, No. 2, Desember 2020, hlm. 57-73

e-ISSN: 2580-0973, p-ISSN: 2580-085X

Tersedia online di: http://syekhnurjati.ac.id/jurnal/index.php/empower

Email: empowerjurnal@gmail.com

\title{
Pemberdayaan Masyarakat di Masa Pandemi COVID-19 oleh PT. Pertamina (Persero) RU II Sungai Pakning
}

\author{
Choirul Muna* \\ (Program Studi Pengembangan Masyarakat Islam, \\ Fakultas Dakwah dan Komunikasi, UIN Sunan Kalijaga) \\ Email: choirulmuna.pmi@gmail.com \\ Modhofir Yusuf Saifulloh** \\ (Program Studi Komunikasi Penyiaran Islam, \\ Fakultas Dakwah dan Komunikasi, UIN Sunan Kalijaga) \\ Email: yus.yusuf25@gmail.com

\section{Fajar Sodik***} \\ (Program Studi Perbankan Syariah, \\ Fakultas Ekonomi dan Bisnis Islam, UIN Sunan Kalijaga) \\ Email: 111fajarsodik@gmail.com
}

\section{Article History}

Submitted: 23.10.2020, Revised: 30.11.2020, Accepted: 14.12 .2020

\begin{abstract}
The spread and increase in the number of COVID-19 cases has occurred very quickly and has even spread in various countries including Indonesia. With the increase in the spread of this virus, it has an impact on various sectors, one of which is the weakening of the economy marked by the high number of layoffs (PHK). In a difficult situation like this, the role of business institutions is needed. For example, through Corporate Social Responsibility (CSR) programs. For example at PT. Pertamina (Persero) RU II Sungai Pakning through donation programs (charity), capacity building and community empowerment. The technical data used in this research is the SOAR model which is analyzed qualitatively based on interview data and literature review. The results of this study indicate that PT. Pertamina (Persero) RU II Sungai Pakning through
\end{abstract}


the Citronella Instant Hand Sanitizer community empowerment program is able to move the economy of the local community, especially lemongrass farmers. This shows the existence of CSR efforts to develop the capacity of fostered partners by maximizing the potential of local wisdom in the current pandemic situation.

Keywords: community empowerment, COVID-19

\begin{abstract}
Abstrak
Penyebaran dan peningkatan jumlah kasus COVID-19 telah terjadi sangat cepat dan bahkan telah menyebar di berbagai negara termasuk Indonesia. Dengan meningkatnya penyebaran virus ini, berdampak pada berbagai sektor, salah satunya adalah melemahnya perekonomian yang ditandai dengan tingginya angka PHK (PHK). Dalam situasi sulit seperti ini, peran institusi bisnis sangat dibutuhkan. Melalui program Corporate Social Responsibility (CSR), PT. Pertamina (Persero) RU II Sungai Pakning melakukan program donasi (amal), peningkatan kapasitas dan pemberdayaan masyarakat. Data teknis yang digunakan dalam penelitian ini adalah model SOAR yang dianalisis secara kualitatif berdasarkan data wawancara dan tinjauan literatur. Hasil penelitian ini menunjukkan bahwa PT. Pertamina (Persero) RU II Sungai Pakning melalui program pemberdayaan masyarakat mampu menggerakkan perekonomian masyarakat setempat, khususnya petani serai. Hal ini menunjukkan adanya upaya CSR untuk mengembangkan kapasitas mitra binaan dengan memaksimalkan potensi kearifan lokal dalam situasi pandemi saat ini.
\end{abstract}

Kata kunci: pemberdayaan masyarakat, COVID-19

\title{
PENDAHULUAN
}

Dunia saat ini dikejutkan dengan mewabahnya penyakit menular yang disebut dengan COVID-19. Dengan adanya wabah ini telah berdampak kepada perekonomian global. Adanya pandemi COVID-19 berakibat kepada perlambatan pertumbuhan ekonomi Tiongkok dari 6,1\% tahun lalu, menjadi hanya sekitar 3,8\% tahun ini, dengan catatan penyebaran virus ini tidak bertambah buruk. Jika keadaan terus memburuk dapat mengakibatkan pertumbuhan ekonomi Tiongkok menjadi 0,1\% bahkan minus. Tentunya hal tersebut berpengaruh terhadap perekonomian global karena, Tingkok 
merupakan negara dengan ekonomi terbesar kedua di dunia. Mobilisasi penduduk dunia yang memiliki konektivitas yang sangat tinggi menyebabkan virus ini cepat menyebar ke seluruh penjuru dunia. Menurut beberapa lembaga riset kredibel dunia, mereka memprediksi dampak buruk penyebaran wabah ini terhadap ekonomi global. JP Morgan memprediksi ekonomi dunia minus $1,1 \%$ ditahun 2020. Kemudian, ekonomi dunia di prediksi mencapai minus 2,2\% oleh EIU, minus 1,9\% oleh Fitch dan IMF memprediksi ekonomi dunia minus 3\% ditahun 2020. Adanya prediksiprediksi ekonomi tersebut sangat mengkhawatirkan masyarakat dunia. ${ }^{1}$

Pandemi COVID-19 juga menjadi perhatian yang besar bagi bangsa Indonesia. Karena banyak kerugian yang timbul dari pandemi ini sehingga berdampak pada perekonomian Indonesia. Setelah mengalami peningkatan yang melesat banyak dalam kurun waktu yang sangat sebentar, pemerintah Indonesia membuat kebijakan dalam upaya mengatasi COVID-19 ini. Salah satu upaya tersebut adalah di berlakukanya PSBB yang tercantum dalam Peraturan Pemerintah No. 21 Tahun 2020. Dengan adanya PSBB menyebabkan semua kegiatan yang biasa dilakukan terpaksa berhenti. Seluruh kegiatan industri hingga perkantoran untuk sementara tidak beroperasi. Selain itu, kebijakan Social distancing dan physical distancing membawa pengaruh pada penurunan aktivitas ekonomi secara keseluruhan. ${ }^{2}$

Bentuk nyata yang nampak dari dampak COVID-19 terhadap ekonomi yang dapat terlihat saat ini adalah banyaknya pekerja yang dirumahkan dan kena PHK. Hasil data yang didapat yaitu, lebih dari 1,5 juta. Dari jumlah tersebut, 90 persen diantaranya dirumahkan dan 10 persen kena PHK. Terdiri dari 1,24 juta orang adalah pekerja formal dan 265 ribu pekerja informal. ${ }^{3}$

1 Khaerul Aqbar Azwar Iskandar, Bayu Taufiq Possumah, "Peran Ekonomi Dan Keuangan Sosial Islam Saat Pandemi COVID-19," SALAM;Jurnal Sosial E Budaya $\begin{array}{llll}\text { Syar }-i & 7, & & \end{array}$ (2020): 625-638, http://journal.uinjkt.ac.id/index.php/salam/article/view/15544/pdf.

2 Ibid.

3 Hanoatubun Silpa, "Dampak COVID-19 Terhadap Perekonomian Indonesia," EduPsyCouns Journal 2, no. 1 (2020): 146-153, https://ummaspul.ejournal.id/Edupsycouns/article/view/423. 
Menurut Undang-Undang No. 24 Tahun 2007 tantang Penanggulangan Bencana terdapat 3 aktor yang terlibat yaitu: pemerintah, masyarakat dan lembaga usaha. Dalam situasi sulit seperti ini, peran lembaga usaha sangat di butuhkan. Menurut undang-undang tersebut adapun peran lembaga usaha yaitu mendapatkan kesempatan dalam penyelenggaraan penanggulangan bencana, baik secara tersendiri maupun secara bersamasama dengan pihak lain. Melalui penyesuaian kegiatan dengan kebijakan penyelenggaraan penanggulangan bencana dan berkewajiban mengindahkan prinsip-prinsip kemanusiaan dalam melaksanakan fungsi ekonominya dalam penanggulangan bencana. ${ }^{4}$

Contohnya pada PT. Pertamina (Persero) RU II Sungai Pakning. Dalam situasi pandemi saat ini, mereka merespons baik dengan membuat strategi baru guna mengoptimalkan tanggung jawab sosial perusahaan kepada masyarakat untuk menjalankan peran lembaga usaha ditengah bencana non alam COVID-19. Strategi yang pertama, yaitu mengalokasikan anggaran untuk donasi (charity) berupa alat kesehatan (APD), paket sembako, bak cuci tangan untuk masyarakat terdampak serta memberikan multivitamin kepada tenaga kesehatan dan Satgas COVID-19. Yang kedua, mengembangkan kapasitas masyarakat (capacity building) menjadi penyuluh dan penggerak hidup sehat serta pencegahan penyebaran virus di tingkat lokal. Seperti pelatihan, penyuluhan dan sosialisasi PHBS (Perilaku Hidup Bersih dan Sehat) dan CTPS (Cuci Tangan Pakai Sabun) kepada kader Posyandu binaan. Selain itu, strategi yang sangat menarik yaitu program pemberdayaan masyarakat (community empowermet) bersama mitra binaan BUMDES Mekar Jaya memproduksi Citronella Instant Hand Sanitizer menggunakan bahan baku minyak atsiri (Citronella) yang diperoleh dari tanaman serai wangi dan merupakan hasil pertanian masyarakat sekitar dan juga alih fungsi Masyarakat Peduli Api (MPS) menjadi Masyarakat Peduli Bencana (MPB) untuk penyemprotan Disinfektan ke desa-desa.

Berangkat dari beberapa hal tersebut, membuat tim peneliti berusaha untuk mengeksplorasi tentang bagaimana kontribusi serta peran perusahaan PT. Pertamina (Persero) RU II Sungai Pakning dalam merespon COVID-19.

4 (UU No. 24 Tahun, 2007) 
Dalam penelitian ini peneliti mencoba menganalisis program CSR perusahaan tersebut dengan pendekatan analisis SOAR.

Ditinjau dari jenis datanya, tim peneliti sepakat menggunakan model penelitian kualitatif. Adapun jenis pendekatan penelitian ini adalah deskriptif, yaitu penelitian yang berusaha untuk menguraikan pemecahan problematika yang ada sekarang berdasarkan data-data. Jenis data yang diambil terdapat 2 macam. Data primer seperti wawancara (interview) secara virtual (online) dengan bapak Miftah Faridl Widhagdha, CSR Officer dari PT. Pertamina (Persero) RU II Sungai Pakning, pada tanggal 7 September 2020. Teknik wawancara digunakan untuk mengungkap data tentang bentuk partisipasi perusahaan, berlangsungnya bentuk partisipasi dan manfaat program citronella instant hand sanitizer.

\section{HASIL DAN PEMBAHASAN}

Dari hasil penelitian pada PT. Pertamina RU II Sungai Pakning, perusahaan besar ini memiliki komitmen yang tinggi terhadap penanganan pandemi COVID-19. Hal ini dapat dicermati melalui alokasi anggaran 30\%65\% CSR dialihkan untuk membantu penanganan COVID-19. Penanggulangan oleh PT. Pertamina RU II Sungai Pakning ada tiga jenis yaitu Charity, Capacity Building dan Community Empowerment. Dari hasil wawancara dengan officer CSR setempat via daring mengungkapkan bawah dengan situasi seperti ini, beban dan tanggung jawab sosial perusahaan menjadi meningkat. Meski bukan merupakan core of the business melainkan hanya sebagai support of the business, CSR tetap memiliki peran yang penting bagi perusahaan karena sejatinya CSR merupakan bagian dari perusahaan yang berfungsi sebagai pendukung keberhasilan kinerja perusahaan itu sendiri.

Disamping itu, PT. Pertamina (Persero) RU II Sungai Pakning mengungkapkan dalam melaksanakan semua program khusunya CSR ini, tentu perusahan selalu menekankan pada aspek 3P, yaitu Profit, People dan Planet. Yang pertama Profit, Dalam menjalankan program ini, pihak perusahaan tidak mendapat keuntungan secara fisik. Keuntungan mereka diperoleh dari produksi bahan bakar minyak. Sedangkan untuk program ini, keuntungan yang mereka dapat bukan dalam bentuk uang, melainkan 
kepuasan dalam menjalankan program tanggung jawab sosial perusahaan yang dapat diterima dan sangat berpengaruh dalam roda perekonomian masyarakat setempat.

Selanjutnya People, dengan adanya berbagai program yang dicanangkan, membuat masyarakat dari BUMDES baik yang berprofesi sebagai petani dan tenaga kerja di Malaysia maupun masyarakat umum yang sempat menganggur akibat pandemi, menjadi bisa bekerja lagi dengan mengikuti program yang diinisiasi oleh CSR Pertamina. Sehingga program ini sangat mengurangi angka pengangguran yang ada disekitar perusahaan.

Terakhir yaitu Planet, dengan memanfaatkan bahan baku tanaman lokal serai wangi, menjadikan proses produksi instant hand sanitizer menjadi lebih mudah. Selain itu, tanaman serai wangi sebelumnya hanya dianggap rumput liar, dengan dijadikan bahan produksi hand sanitizer, tentu menjadikan tanaman ini dapat lebih bermanfaat dan berguna. Selain itu tanaman ini dapat dibudidayakan serta dikembangkan untuk inovasi inovasi produk lainnya.

\section{Charity}

Dalam program yang dijalankan di masa pandemi, semuanya tetap memiliki nilai dan urgensinya tersendiri. Seperti pemberian donasi (charity) yang telah dilakukan, program ini adalah wujud dari respons secara langsung (mendesak) yang diberikan oleh pihak perusahaan. Perusahaan menyadari bahwa dalam menghadapi pandemi ini akan ada hal-hal yang bersifat dadakan dan sangat dibutuhkan, contohnya pada bidang kesehatan seperti APD. Pada awal pandemi alat tersebut sulit untuk diperoleh dan hanya tersedia di daerah-daerah tertentu (kota-kota besar). Selain itu, alat cuci tangan di tempat umum juga sangat jarang ditemui, terutama di kabupaten Bengkalis. Kita ketahui bahwa salah satu cara untuk mengurangi penyebaran COVID-19 ini dengan rajin cuci tangan. Oleh karena itu, melihat jumlah alat untuk mencegah penyebaran virus yang terbatas, maka pihak PT. Pertamina RU II Sungai Pakning mengambil inisiatif untuk memberikan bantuan atau donasi. Bantuan tersebut berupa APD, alat cuci tangan serta multivitamin yang diberikan terutama kepada Tenaga Kesehatan dan Satgas COVID-19. 


\section{Capacity Building}

Pengembangan kapasitas (capacity building) dalam situasi pandemi saat ini sangat perlu dilakukan. CSR PT. Pertamina (Persero) RU II Sungai Pakning menyadari bahwa merespons pandemi tidak cukup jika hanya dengan menyiapkan alat-alat kesehatan saja. PT. Pertamina (Persero) RU II Sungai Pakning melakukan program sosialisasi bahaya dan pencegahan COVID-19 kepada anak sekolah melalui game interaktif ANAK SIAGA COVID-19 (ASIC) melalui Website http://sekolahcintagambut.com/. Selanjutnya produksi madu hutan oleh BUMDES Tanjung Leban untuk penambah imunitas bagi tenaga kesehatan dan masyarakat umum di wilayah Sungai Pakning. Selain itu, pihak perusahaan juga mengadakan pelatihan, penyuluhan dan sosialisasi PHBS (Perilaku Hidup Bersih Sehat) dan CTPS (Cuci Tangan Pakai Sabun) kepada Kader Posyandu binaan. Sehingga dengan melakukan pengembangan kapasitas (capacity building) melalui program pelatihan, penyuluhan dan sosialisasi diharapkan masyarakat semakin kuat dan siap dalam menghadapi pandemi. Dengan harapan, adanya program ini membuat pandemi dapat segera berakhir tanpa menambah jumlah kasus yang baru.

\section{Community Empowerment}

Di samping dalam memberikan donasi dan pengembangan kapasitas kepada masyarakat, pihak PT. Pertamina (Persero) RU II Sungai Pakning juga sangat memperhatikan perekonomian masyarakat.. Apabila ditarik mundur kebelakang, pertumbuhan ekonomi Indonesia pada 2020 semula diperkirakan sebesar 5,3\%, namun angka ini terkoreksi sebagai dampak pandemi Corona, dan sebagian kalangan memprediksikan pertumbuhan di bawah $2 \%$. Mengingat terjadi ketidakpastian dan prediksi berbeda-beda, serta terjadi fluktuasi kurs USD (peningkatan drastis menjadi Rp 16.000 per USD pada awal April 2020). ${ }^{5}$

Akibat dari wabah ini, Menteri Ketenagakerjaan Ida Fauziyah, mengakui bahwa pandemi COVID-19 telah memberikan dampak di seluruh

\footnotetext{
5 Wibowo Hadiwardoyo, "Kerugian Ekonomi Nasional Akibat Pandemi COVID-19," Baskara Journal of Business and Enterpreneurship 2, no. 2 (2020): 83-92, https://jurnal.umj.ac.id/index.php/baskara/article/view/6207.
} 
sektor perekonomian yang muaranya pada sektor ketenagakerjaan. Jumlah pekerja yang terdampak situasi pandemi COVID-19 mencapai 1,7 juta orang, baik pekerja formal maupun informal ${ }^{6}$. Dari situlah yang menyebabkan perekonomian di berbagai daerah mengalami penurunan. Maka dari itu dengan mempertimbangkan aspek-aspek kesehatan, pihak PT. Pertamina (Persero) RU II Sungai Pakning tetap mengambil langkah untuk tetap melakukan pemberdayaan masyarakat (community empowerment) supaya dapat menghidupkan kembali perekonomian masyarakat setempat.

\section{Pelatihan dan Pembuatan Citronella Instant Hand Sanitizer Sebagai Inovasi Sosial PT. Pertamina (Persero)RU II Sungai Pakning}

Salah satu program inovatif dan bersifat community empowermet dari PT. Pertamina (Persero) RU II Sungai Pakning adalah dengan membantu masyarakat BUMDES Mekar Jaya dalam membuat Citronella Instant Hand Sanitizer. Produk yang berkomposisi terdiri dari Etanol 96\%, Gliserol 98\%, Hidrogen Peroksida 3\%, Citronella oil 2\% dan Aquadest, sekarang telah terproduksi sebanyak 4000 botol setiap minggunya.

Hal yang menjadikan urgensi kenapa pertamina bersama BUMDES membuat program pembuatan hand sanitizer ini ialah pertamina percaya di era pandemi kebutuhan alat kesehatan akan semakin meningkat dan tingkat kesadaran masyarakat akan semakin tinggi. Terlebih jika ditarik mundur beberapa bulan lalu Indonesia sempat mengalami kelangkaan stok hand sanitizer, hal ini membuat harganya kian meroket tajam, dari case inilah menjadikan landasan pertamina mengadakan program pelatihan ini. Tidak sampai terhenti disini saja, pertamina juga berkomitmen kalau vaksin sudah ditemukan dan pemerintah sudah bisa menangani pandemi ini, program ini akan terus dilaksanakan karena dipercaya budaya dan gaya hidup masyarakat akan berubah, masyarakat akan semakin aware dengan kesehatan mereka. Sehingga pertamina tetap yakin permintaan pasar akan tetap tinggi.

\footnotetext{
6 Biro Humas (Kementrian Ketenagakerjaan) Kemnaker, "Pemerintah Antisipasi Penambahan Pengangguran Di Masa Pandemi COVID-19," Kemnaker.Co.Id, last modified 2020, accessed September 19, 2020, https://kemnaker.go.id/news/detail/pemerintah-antisipasi-penambahanpengangguran-di-masa-pandemi-COVID-19.
} 
Guna mewujudkan tercapainya program pembuatan hand sanitizer, CSR PT. Pertamina (Persero) RU II Sungai Pakning bersama mitra BUMDES Mekar Jaya melakukan pelatihan atau training kepada masyarakat setempat khususnya petani disana. Terkait tentang bagaimana cara mengelola serai wangi menjadi hand sanitizer dengan dibantu oleh Universitas Riau. Kendala terbesar dari program hand sanitizer terletak di masyarakatnya. Karena belum mengetahui dan memahami alur proses pembuatan dan pengelolaan hand sanitizer.

Semenjak CSR pertamina menggulirkan program pembuatan hand sanitizer nampaknya mulai membuahkan hasil, dengan penggelontoran dana 100 juta rupiah oleh CSR pertamina, dimanfaatkan dengan sangat maksimal, mulai dari pengembangan di sektor pertaniannya, penanganan atau pengelolaan hingga pemasaran. Indikator kesuksesan bisa dilihat dari angka permintaan pasar yang kian meningkat. Setiap minggunya bisa memproduksi 4000 botol hand sanitizer, hal yang membuat angka permintaan pasar tinggi adalah dari harga yang ekonomis. BUMDES mematok harga yang relatif lebih rendah daripada competitor lainnya, sehingga masyarakat tertarik dengan hand sanitizer yang murah.

Namun, hand sanitizer ini masih dijual untuk pasar lokal saja atau dengan kata lain belum mampu menjangkau pasar nasional. Karena ketika melakukan penjualan sampai luar pulau terjadi pembengkakan di ongkos pengiriman. Bisa dikatakan hasil dari produk ini tidak hanya digunakan oleh masyarakat sekitar, tetapi juga dikomersilkan juga, agar BUMDES dan masyarakat mendapatkan keuntungan sehingga roda perekonomian akan terus berkembang.

\section{Analisis Keberhasilan Program CSR PT. Pertamina (Persero) RU II Sungai Pakning.}

Selanjutnya untuk mengetahui tingkat keberhasilan program yang digulirkan selama menghadapi pandemi, tim peneliti menggunakan pendekatan SOAR sebagai berikut;

\section{Strenght (Kekuatan)}

PT. Pertamina (Persero) RU II Sungai Pakning merupakan salah satu perusahaan yang besar. Kilang produksi BBM RU II Sungai Pakning adalah 
bagian dari Pertamina RU II Dumai yang merupakan kilang minyak dari business group (BG) pengolahan Pertamina. Tenaga kerja yang mendukung kegiatan produksi kilang PT. Pertamina (Persero) RU II Sungai Pakning adalah 207 pekerja Pertamina dan 61 pekerja PT EPT. Selama periode pelaporan, Pertamina sudah mencairkan Dana Program Kemitraan kurang lebih Rp 516 miliar kepada 2.067 mitra di berbagai sektor, termasuk perdagangan, industri, pertanian, perkebunan, peternakan, perikanan, jasa, dan lain-lain. Sebanyak 62.405 UMKM menjadi mitra binaan Pertamina sejak tahun 1993 hingga akhir 2019. ${ }^{7}$

BUMDES Mekar Jaya adalah salah satu mitra binaan dari PT Pertamina (Persero) RU II Sungai Pakning. BUMDES ini mengandalkan hasil pertanian lokal. Dengan bantuan sebesar 100 juta rupiah, desa binaan ini berhasil disulap menjadi desa yang lebih baik dari sebelumnya. Ketika awal pandemi, desa ini sama seperti desa-desa yang lainnya, mengalami kesusahan dalam mencukupi kebutuhan dasar. Akan tetapi dengan membuat produk hand sanitizer yang berbahan baku dari tanaman serai wangi, membuat perekonomian daerah setempat berkembang. Produk ini diminati oleh masyarakat dikarenakan harga produk hand sanitizer ini lebih murah dibanding produk lainnya. Sehingga program ini mampu menghasilkan keuntungan yang banyak. Bahkan untuk jumlah produksinya mencapai 4000 botol per minggu.

\section{Opportunity (Peluang)}

Merebaknya wabah COVID-19 sempat menyebabkan kelangkaan alat kesehatan dan hand sanitizer pada awal - awal pandemi (social safety net). Dengan mengetahui permasalahan tersebut, PT. Pertamina (Persero) RU II Sungai Pakning mengambil sebuah langkah. Setelah memberikan bantuan yang bersifat mendesak, selanjutnya melaksanakan langkah yang tepat dengan melakukan pengembangan kapasitas kepada masyarakat (capacity building). Sehingga masyarakat mampu bertahan dan mampu menyesuaikan diri dalam kondisi pandemi saat ini. PT. Pertamina (Persero) RU II Sungai Pakning juga tepat dalam menentukan sasarannya, yaitu dengan membuat

\footnotetext{
7 Tim Redaksi PT. Pertamina, Sustainability Report Pertamina 2019, 2019.
} 
program yang mampu dilakukan oleh semua lapisan masyarakat mencakup anak-anak hingga dewasa. Sehingga masyarakat merespons dengan apresiasi yang baik dan mampu mementingkan kesehatan.

\section{Aspiration (Aspirasi)}

Program kerja tahunan CSR PT. Pertamina (Persero) RU II Sungai Pakning pada bulan Januari sudah tersusun. Namun, ketika negara mengumumkan kasus COVID-19yang pertama pada bulan Maret, CSR PT. Pertamina (Persero) RU II Sungai Pakning dengan cepat pada bulan April mengubah program kerjanya menyesuaikan dengan kondisi yang sedang terjadi. Pihak CSR perusahaan mampu memodifikasi program menjadi pencegahan dan mitigasi COVID-19. Program yang sebelumnya top down menjadi button up dengan tetap memprioritaskan program empowerment $60 \%$ yang bersifat karikatif.

\section{Result (Hasil)}

Alat kesehatan termasuk hand sanitizer pada awal pandemi COVID19 menjadi produk yang dicari-cari oleh masyarakat di indonesia. Kelangkaan ini mampu dijawab oleh CSR PT Pertamina RU II Sungai Pakning bermitra dengan desa binaan dan Universitas Riau untuk membuat Citronella InstantHand Sanitizer sesuai standar WHO. Sehingga kebutuhan masyarakat akan hand sanitizer mampu dipenuhi dari hasil produksi Citronella InstantHand Sanitizer ini. Bahkan produk ini mampu menyebar ke beberapa daerah sampai menguasai pasar lokal yang berada di kabupaten Bengkalis. Dengan harga yang lebih murah dibanding produk lainnya, menjadikan produk ini dapat dinikmati oleh masyarakat umum. Sehingga hasil yang tercapai tidak hanya mampu memproduksi saja tetapi mampu meningkatkam kesejahteraan masyarakat setempat sekaligus menambah khas BUMDES.

\section{Matriks SOAR}

Berdasarkan faktor internal dan eksternal yang ada pada situasi pandemi, prospek program CSR PT. Pertamian (Persero) RU II Sungai 
Pakning sesuai dengan pembahasan di atas dapat di gambarkan dalam tabel di bawah ini:

Tabel 1. Matriks SOAR

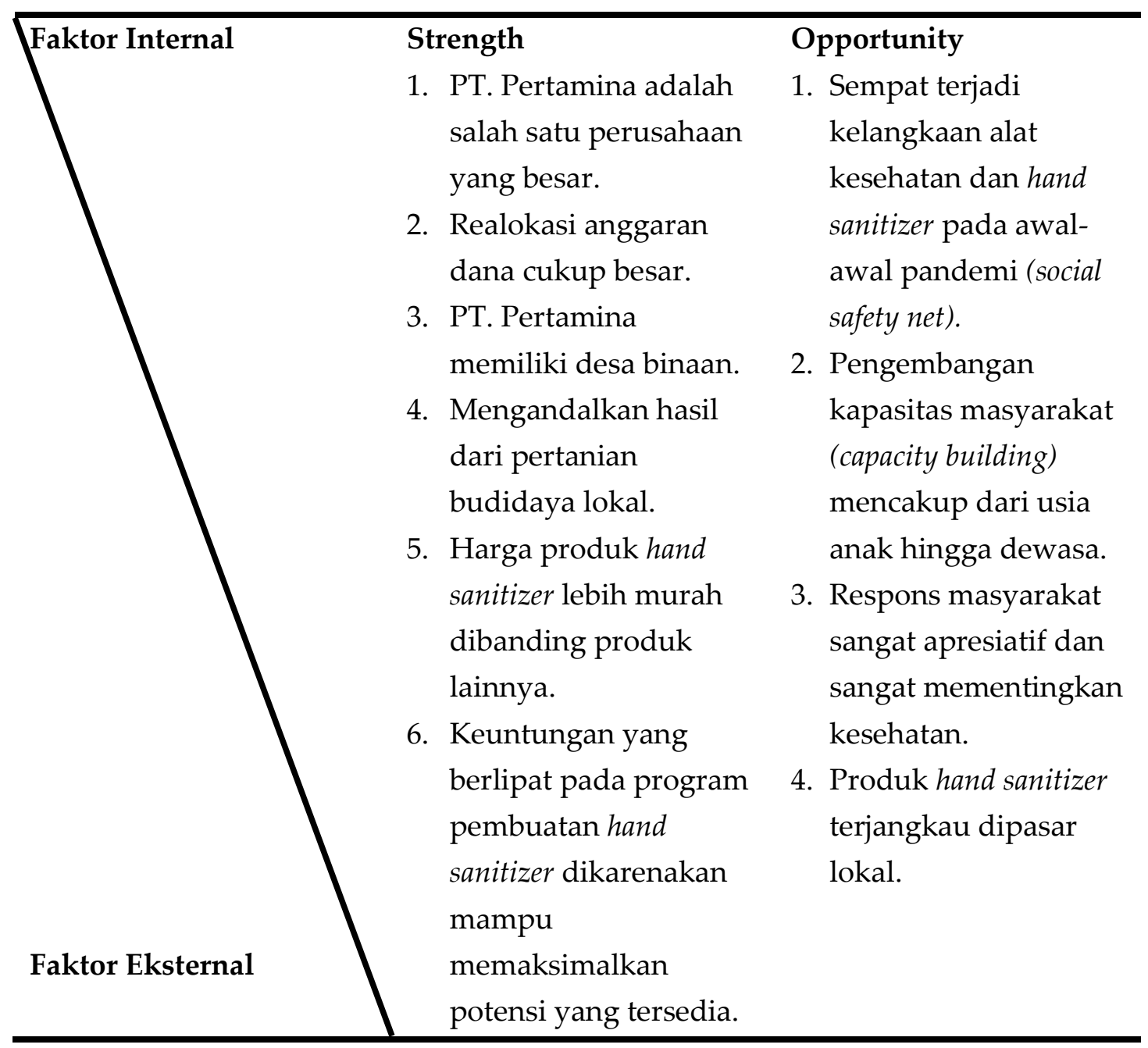




\section{Aspiration}

1. Pihak perusahaan mampu memodifikasi program seperti pencegahan dan mitigasi.

2. Program yang sebelumnya top down menjadi button up dengan tetap memprioritaskan program empowerment $60 \%$ yang bersifat karikaktif.

\section{Strategi SA}

1. Memaksimalkan SDM CSR PT. Pertamina RU II Sungai Pakning.

2. Realokasi anggaran program sosial yang terus meningkat setiap tahunnya.

3. Menjalin banyak relasi dengan institusi atau pihak yang memiliki program inovasi sosial.

4. Melebarkan jangkauan pemberdayaan.

\section{Strategi OA}

1. Teliti dalam memperhatikan fenomena-fenomena sosial.

2. Mampu dalam menguraikan problem sosial dari yang bersifat urgent sampai dengan yang tersederhana.

3. Memaksimalkan potensi kearifan lokal.

4. Melebarkan sayap usaha dan memperluas jangkauan marketing.

\section{Strategi OR}

\section{Result}

1. Perusahaan memperoleh 3P, yaitu Profit, People dan Planet.

2. Mitra Perusahaan memperoleh keuntungan ekonomi.

3. Masyarakat umum menjadi dimudahkan dalam mendapatkan fasilitas dan sarana kesehatan.

\section{Strategi SR}

1. Stabilitas mutu kualitas kinerja dari CSR perusahaan.

2. Mengutamakan transparansi dalam bermitra dengan institusi yang terkait.

3. Keuntungan sepenuhnya harus diutamakan untuk masyarakat.
1. Mengembangkan pertanian budidaya serai.

2. Senantiasa melibatkan masyarakat dalam melaksanakan program.

3. Pengembangan kapasitas kepada desa binaan terkait dalam memaksimalkan potensi kearifan lokal. 


\section{SIMPULAN}

Berdasarkan hasil analisis dan pembahasan, penulis memperoleh kesimpulan, sebagai berikut:

Pertama, hasil penelitian ini menunjukkan komitmen yang serius dari CSR PT. Pertamina (Persero) RU II Sungai Pakning dalam merespons pandemi. Mulai dari memantapkan program Capacity Building, terus aktif dalam kegiatan charity dan yang paling menjadi pusat perhatian adalah keberhasilan program-program community empowerment-nya.

Kedua, dari ketiga program utama CSR itu direalisasikan dengan membuat lima program. Pertama fungsi Masyarakat Peduli Api (MPA) di 10 Desa Binaan menjadi Masyarakat Peduli Bencana (MPB), Kedua, produksi madu hutan oleh BUMDES Tanjung Leban, Ketiga, sosialisasi bahaya dan pencegahan COVID-19 kepada anak sekolah melalui game interaktif ANAK SIAGA COVID-19 (ASIC), Keempat, pelatihan pembuatan Hand Sanitizer, Kelima, produksi Hand Sanitizer dengan bahan baku minyak atisiri citronella yang diproduksi oleh mitra binaan BUMDES Mekar Jaya.

Ketiga, penelitian ini menunjukkan keberhasilan program CSR Pertamina terutama dari sisi community empowerment-nya, ini dilihat dari indikasi semakin meningkatnya permintaan pasar dari produk instant hand sanitizer. Setiap minggunya mitra binaan Pertamina mampu memproduksi sekitar 4000 botol. Sehinggga menyebabkan terciptanya masyarakat yang lebih aware dengan kebersihan.

Keempat, berdasarkan hasil analisis SOAR, tim peneliti menyimpulkan adanya peluang yang besar terutama pada program pembuatan instant hand sanitizer. Apabila dilihat dari segi kekuatan, kesempatan, aspirasi dan hasil program ini memiliki prospek yang sangat bagus dan dapat menjadi lebih besar di kemudian hari. Melalui kerja sama kuat antara CSR PT. Pertamina (Persero) RU II Sungai Pakning, BUMDES Mekar Jaya serta Universitas Riau, membuat program ini dapat dengan cepat berkembang. Program ini juga memiliki nilai tambah tersendiri karena berhasil memaksimalkan hasil potensi kearifan lokal. Kebutuhan akan hand sanitizer di masa pandemi juga memiliki pengaruh yang besar. Selain itu, strategi penjualan produk dengan mematok harga yang lebih rendah dari 
kompetitor, menyebabkan produk tersebut banyak di minati oleh masyarakat umum.

\section{DAFTAR PUSTAKA}

Adelia Alfama Zamista, Hanafi. "Analisis SOAR Pada Strategi Pemasaran Di Industri Jasa Finance." JURNAL TEKNIK INDUSTRI 6, no. 1 (2020): 2733. http://ejournal.uin-suska.ac.id/index.php/jti/article/view/9335.

Azwar Iskandar, Bayu Taufiq Possumah, Khaerul Aqbar. "Peran Ekonomi

Dan Keuangan Sosial Islam Saat Pandemi COVID-19." SALAM;Jurnal Sosial \& Budaya Syar-i 7, no. 7 (2020): 625-638. http://journal.uinjkt.ac.id/index.php/salam/article/view/15544/pdf.

Hadiwardoyo, Wibowo. "Kerugian Ekonomi Nasional Akibat Pandemi COVID-19." Baskara Journal of Business and Enterpreneurship 2, no. 2 (2020):

83-92.

https://jurnal.umj.ac.id/index.php/baskara/article/view/6207.

Kemenkes RI. “KMK No. HK.01.07-MENKES-413-2020 Tentang Pedoman Pencegahan Dan Pengendalian COVID-19," 2020.

Kemnaker, Biro Humas (Kementrian Ketenagakerjaan). "Pemerintah Antisipasi Penambahan Pengangguran Di Masa Pandemi COVID-19."

Kemnaker.Co.Id. Last modified 2020. Accessed September 19, 2020.

https://kemnaker.go.id/news/detail/pemerintah-antisipasi-

penambahan-pengangguran-di-masa-pandemi-COVID-19.

Mudjarad, Kuncoro, and Ancok Tandelilin, Eduardus Djamaludin.

Tranformasi Pertamina. Edited by A.tony Prasentiantono. 1st ed.

Yogyakarta: Galangpress, 2009.

https://books.google.co.id/books?hl=id\&lr=\&id=VS7M1QisNv0C\&oi=fn $\mathrm{d} \& \mathrm{pg}=$ PR5\&dq=related:-TF7NYJZ-

SkJ:scholar.google.com/\&ots=9m0xh2AaPc\&sig=A8dZVVORiM6fmm0

djlj0yIAifi4\&redir_esc $=\mathrm{y} \# \mathrm{v}=$ onepage $\& \mathrm{q}=(\mathrm{PKBL}) \& \mathrm{f}=$ false.

Noor, Hadi. Corporate Social Responsibility. Yogyakarta: Graha Ilmu, 2011.

Noor, Munawar. "PEMBERDAYAAN MASYARAKAT." Jurnal Ilmiah CIVIS

1, no. 2 (2011):

87-99.

http://103.98.176.9/index.php/civis/article/view/591. 
Nurjanah, Adhianty. "PEMBERDAYAAN MASYARAKAT URBAN(MISKIN PERKOTAAN)PT SARI HUSADA YOGYAKARTAMELALUI PROGRAMCORPORATE SOCIAL RESPONSIBILITY(CSR)RUMAH SRIKANDI" (2018): 1-17. http://repository.umy.ac.id/bitstream/handle/123456789/1392/PNLT223 4.pdf?seq.

Prayogo, Dody. Socially Responsible Corporation: Peta Masalah, Tanggung Jawab Sosial, Dan Pembangunan Komunitas Pada Industri Tambang Dan Migas. Jakarta: Universitasa Indonesia (UI Press), 2011.

Rasyid, Anuar, Saleh Amiruddin, Hafied Canggara, and Wahtyu Budi

Priatna. "Komunikasi Dalam CSR Perusahaan: Pemberdayaan Masyarakat Dan Membangun Citra Positif." MIMBAR 31, no. 2 (2015): 507-518.

https://ejournal.unisba.ac.id/index.php/mimbar/article/viewFile/1564/1 130.

Republik Indonesia. Undang-Undang Republik Indonesia Nomor 24 Tahun 2007 Tentang Penanggulangan Bencana. Diundangkan Pada 10 Maret 2007, 2007. Romi, Marnelly. “CORPORATE SOCIAL RESPONSIBILITY (CSR):Tinjauan Teori Dan Praktek Di Indonesia." Jurnal Aplikasi Bisnis 2, no. 2 (2012): 49 59.

https://www.academia.edu/30213987/Akuntansi_Pertanggungjawaban _sosial_Corporate_sosial_Responbilitty_.

Sarwono, Jonathan. Metode Riset Skripsi: Pendekatan Kuantitatif (Menggunakan Prosedur SPSS). Jakarta: Gramedia, 2012.

Silpa, Hanoatubun. "Dampak COVID-19 Terhadap Perekonomian Indonesia." EduPsyCouns Journal 2, no. 1 (2020): 146-153. https://ummaspul.ejournal.id/Edupsycouns/article/view/423.

Stavros, and Saint. Linking Strategy and OD to Suistainable Performance. Practicing Organization Development: U Guide for Leading Change, 2010.

Suharto. Membangun Masyarakat Memberdayakan Masyarakat: Kajian Strategis Pembangunan Kesejahteraan Sosial \& Pekerjaan Sosial. Bandung: Rafika Aditama, 2005.

Sutejo, Bambang. "IMPLEMENTASI PROGRAM CORPORATE SOCIAL 
RESPONSIBILITY (CSR) PT. PERTAMINA ( PERSERO ) REFINERY UNIT II SUNGI PAKNING DALAM MENCIPTAKAN CITRA POSITIF DI KALANGAN MASYARAKAT DESA SUKAJADI KECAMATAN BUKIT BATU KABUPATEN BENGKALIS." UNIVERSITAS ISLAM NEGERI SULTAN SYARIF KASIM， 2010. http://repository.uinsuska.ac.id/id/eprint/11188.

Syahdiyah Sugiarti, Wiwid. "Analisis Strategi Pemasaran Produk Usaha Mikro Kecil Menengah Melalui Metode Analisis Soar (Strength, Opportunity, Aspirations, Result) Studi Pada UMKM Kue Cubit Laina Di Medan." UNIVERSITAS SUMATERA UTARA, 2017. http://repository.usu.ac.id/handle/123456789/66381.

Syahyuti. 30 Konsep Penting Dalam Pembangunan Pedesaan Dan Pertanian. Jakarta: Bina Rena Pariwara, 2006.

Tim Redaksi PT. Pertamina. Sustainability Report Pertamina 2019, 2019.

Yuniarti Wahyuningrum, Irwan Noor, Abdul Wachid. "Pengaruh Program Corporate Social Responsibility Terhadap Peningkatan Pemberdayaan Masyarakat (Studi Pada Implementasi CSR PT. Amerta Indah Otsuka Desa Pacarkeling Kecamatan Kejayan Kabupaten Pasuruan)." Jurnal Administrasi Publik Mahasiswa Universitas Brawijaya 1, no. 5 (2014): 109115.

http://administrasipublik.studentjournal.ub.ac.id/index.php/jap/article/ view/340.

Zonapekan.com. "Penanganan Virus Corona, Ini Daftar 44 Rumah Sakit Rujukan Di Riau." ZONAPEKAN.Com. Last modified 2020. Accessed September 19 , 2020. https://zonapekan.com/news/detail/1335/penanganan-virus-corona-inidaftar-44-rumah-sakit-rujukan-di-riau. 